\title{
Characteristics of thin surface layers of cobalt-based alloys deposited by laser cladding ${ }^{\text {负 }}$
}

\author{
W.C. Lin, C. Chen* \\ Department of Materials Science and Engineering, National Taiwan University, 1 Roosevelt Rd., Sec. 4, Taipei 106, Taiwan
}

Received 3 December 2004; accepted in revised form 30 March 2005

Available online 23 May 2005

\begin{abstract}
Thin surface layers of cobalt-based alloys (Stellite 6 and Tribaloy T-900) and 410 stainless steel (SS) were deposited on mild steel substrates by a coaxial laser cladding process. This process could produce a thin surface layer of less than $0.5 \mathrm{~mm}$ with low energy input. Laser-clad Stellite 6 and Tribaloy T-900 specimens exhibited refined dendritic microstructure. The interdendritic eutectics consisted of either small carbides or intermetallic compounds randomly distributed in a cobalt-rich solid solution, unlike the lamellar structure as observed in conventional weld overlays. The hardness values of the laser-clad layers were generally higher than those of conventional welding deposits owing to the refined effect. The wear and corrosion resistance of S-6 and T-900 specimens were considerably better compared to those of laser-clad 410 SS specimens. In addition, the T-900 specimen had substantially lower corrosion rates than the S-6 specimen in hydrochloric acid solution. Experimental results indicated that wear and corrosion characteristics of the T-900 specimen were excellent; however, preheating was required to avoid cracking in the laser cladding process.
\end{abstract}

(C) 2005 Elsevier B.V. All rights reserved.

Keywords: Laser cladding; Cobalt-based alloys; Abrasive wear; Corrosion; Microstructure

\section{Introduction}

Cobalt-based alloys are widely used in wear-related applications because of their inherent high-strength, corrosion resistance, and retained hardness over a wide temperature range [1]. The hardness of cobalt-based alloys is derived generally from the high hardness of carbides or intermetallic compounds in the cobalt-rich solid solution. The abrasion resistance of these alloys is dependent on the volume fraction, size, and morphology of these hard particles [2,3]. The corrosion resistance of cobalt-based alloys is generally good in many environments. Nevertheless, the corrosion resistance in terms of corrosion rate of a given alloy depends on type, concentration, and temperature of the acidic solution $[1,4]$.

\footnotetext{
t5 This paper has neither been published previously nor submitted for publication elsewhere.

* Corresponding author. Tel.: +8862 2392 5330; fax: +886223634562.

E-mail address: gchen@ntu.edu.tw (C. Chen).
}

The Stellite and Tribaloy alloys (trademarks of the Deloro Stellite Company, Inc.) are wear-resistant cobaltbased alloys, in which Stellite 6 is the most versatile material and well-suited for a wide range of hardfacing applications $[4,5]$. Microstructurally, the wear resistance of Stellite 6 alloy is attributed to the highness of $\mathrm{M}_{7} \mathrm{C}_{3}$ carbides at interdendritic regions in both as-cast and as-welded conditions [1]. A detailed discussion of microstructural features and mechanical properties of Stellite 6 laser coatings has been presented elsewhere [6]. Conversely, Tribaloy alloys consist of a hard Laves phase in a softer matrix of eutectic or solid solution, which are particularly useful for unlubricated wear situations [7,8]. Tribaloy T-900 was developed for improved crack resistance in the Tribaloy family by increasing the $\mathrm{Ni}$ content significantly and reducing Mo of Tribaloy T-800 alloy [9].

Laser cladding is an advanced coating technology which has the advantage of depositing a thin surface coating on the selected area of metal substrates with controlled thickness. It is characterized by a short interaction time of the high 
energy density beam with the powder and the substrate. As a result, the process has a low energy input and causes less distortion of the component than conventional welding methods. Steen [10] and Bruck [11] gave good overviews on the laser surface processes. In the coaxial laser cladding process, metal powder is injected through a nozzle, which is coaxial with laser beams. The powder absorbs laser energy and becomes partially melt before reaching the substrate. Part of the laser energy is also absorbed by the substrate to cause surface melting, forming a strong metallurgical bond between the substrate and the clad layer. Laser cladding can be used not only in the new production but also in the restoration of worn components. Laser-clad layers with defect-free and low dilution have been reported $[12,13]$.

The purpose of this study was focused on the surface properties of laser-clad Stellite 6 and Tribaloy T-900 specimens. Laser-clad 410 SS specimens were also conducted in the experiment for comparison. Surface properties such as wear and corrosion behavior of various laser-clad specimens were determined by abrasive wear and potentiodynamic tests, respectively. In addition, microstructural examinations and microhardness profiles were carried out on laser-clad specimens.

\section{Experimental procedures}

The substrate of test coupons $(100 \mathrm{~mm} \times 25 \mathrm{~mm} \times 9 \mathrm{~mm})$ used in laser cladding experiments was a mild steel, with the chemical composition (wt.\%) of Fe-0.66 Mn-0.27Si. The test coupons were polished and cleaned prior to laser cladding. Stellite $6(38 \sim 125 \mu \mathrm{m})$ and Tribaloy T-900 $(53 \sim 180 \mu \mathrm{m})$ powders were laser-sprayed on the top surface of test coupons. The nominal composition (wt.\%) of the alloy powders used in the experiment is listed in Table 1.

In laser cladding experiments, a Rofin-Sinar $850 \mathrm{CO}_{2}$ laser equipped with a powder feed nozzle was employed. Fig. 1 shows the schematic diagram of such a nozzle, which is similar to the nozzle used in laser powder welding [14]. The spot size of a defocused laser beam at the stand-off distance, i.e. the substrate surface, is approximately $4.1 \mathrm{~mm}$. Table 2 lists the laser cladding parameters utilized in the investigation, in which the overlap between laser tracks is about $33 \%$ and the clad width on the surface for a single track is about $2.3 \mathrm{~mm}$. After cladding, no heat treatments were made on these specimens. The clad layers were

Table 1

Nominal composition (wt.\%) of the experimental powders

\begin{tabular}{llllllllllll}
\hline $\begin{array}{l}\text { Alloy } \\
\text { powder }\end{array}$ & \multicolumn{1}{l}{ Element } & Co & Cr & C & W & Mo & Ni & Si & Fe & Mn & S \\
\hline & S-6 & Bal & 28.5 & 1.12 & 5.06 & 0.35 & 1.34 & 1.33 & 0.99 & 0.4 & 0.01 \\
T-900 & Bal & 18 & 0.08 & - & 23 & 16 & 2.7 & - & - & - \\
$410 \mathrm{SS}$ & - & 12.5 & 0.15 & - & 0.02 & 0.11 & 0.51 & Bal & 0.14 & 0.01 \\
\hline
\end{tabular}

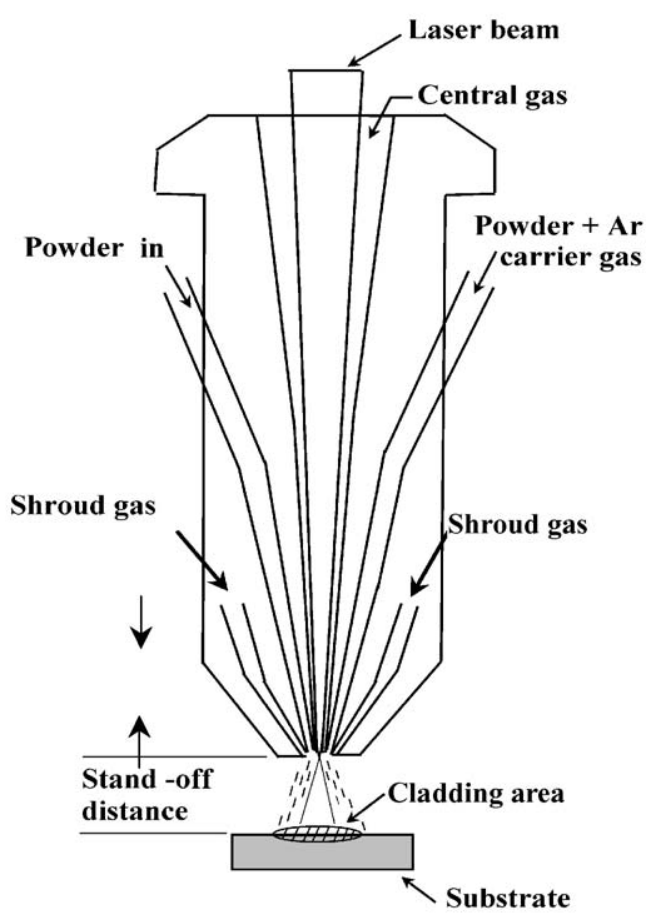

Fig. 1. Schematic diagram of the coaxial powder feed nozzle used in laser cladding.

characterized by means of metallographic examinations and microhardness measurements. For detailed microstructural analyses, transmission electron microscopy (TEM) specimens were sectioned in slices parallel to the laser-clad surface. Care has been taken to ensure that TEM thin foils were obtained within top $0.2 \mathrm{~mm}$ surface layer to avoid the influence of dilution. Thin foils were prepared by a standard jet-polisher using an electrolyte of $15 \%$ perchloric acid $15 \%$ acetic acid, and $70 \%$ methanol at $-40{ }^{\circ} \mathrm{C}$ and then examined with a JEOL-2000EX microscope operated at $200 \mathrm{kV}$.

The abrasive wear tests were performed using a pin-ondisc apparatus. The disc was a grade $80 \mathrm{SiC}$ cutting wheel with a diameter of $205 \mathrm{~mm}$ and $2 \mathrm{~mm}$ thick. Pin specimens $(\varphi 10 \mathrm{~mm} \times 9 \mathrm{~mm})$ were prepared from laser-clad coupons by using an electrode-discharge wire cutter. Pin specimens were ground to grade 1000 abrasive paper prior to testing. Wear tests were performed under dry conditions by a

Table 2

Laser cladding parameters utilized in the investigation

Laser power

Travel speed

Stand-off distance

Shroud gas flow rate

Central gas flow rate

Carrier gas flow rate

Metal powder flow rate

Preheat temperature
S-6 and T-900: $2.5 \mathrm{~kW}$

410 SS: $3.0 \mathrm{~kW}$

$600 \mathrm{~mm} / \mathrm{min}$

23 to $25 \mathrm{~mm}$

$10 \mathrm{l} / \mathrm{min}, \mathrm{Ar}$

$8 \mathrm{l} / \mathrm{min}, \mathrm{He}$

$31 / \mathrm{min}, \mathrm{Ar}$

$13 \mathrm{~g} / \mathrm{min}$

$250{ }^{\circ} \mathrm{C}$ : T-900

None: S-6 \& 410 SS 


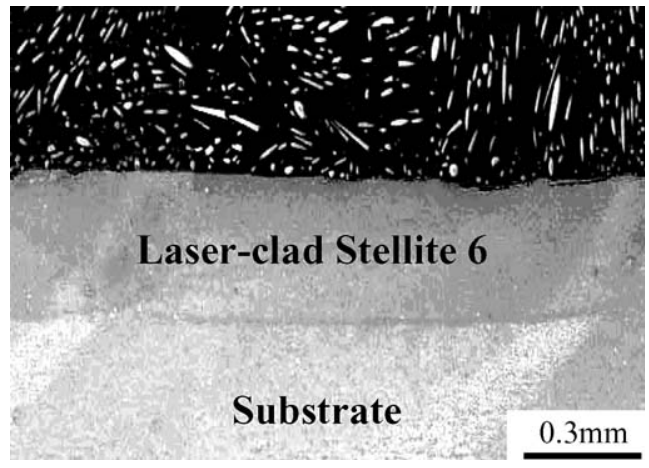

Fig. 2. Typical low-magnification photograph of laser-clad specimens.

rotating (50 rpm) $\mathrm{SiC}$ wheel and an applied a load of $4.9 \mathrm{~N}$ $(0.5 \mathrm{~kg})$ on the pin specimen at room temperature. The speed of disc ( $\mathrm{SiC}$ wheel) at the pin's location was $0.42 \mathrm{~m} / \mathrm{s}$ and each wear test was conducted using a fresh wheel. The weight losses of pins were measured after every $100 \mathrm{~m}$ of sliding distance up to $1000 \mathrm{~m}$.

The potentiodynamic behavior of laser-clad layers was studied in nitrogen purged $0.1 \mathrm{M} \mathrm{HCl}$ and $0.5 \mathrm{M} \mathrm{HCl}$ solutions at room temperature. The electrochemical cell was a conventional three-electrode cell consisting of a working electrode, a saturated calomel reference electrode (SCE), and a platinum counter electrode. The specimens that were connected to the working electrode were polished with up to 1000 grit $\mathrm{SiC}$ abrasive paper. The exposed surface area of specimens to solutions was $10 \mathrm{~mm} \times 5 \mathrm{~mm}$. The potentiodynamic curves were determined with a Princeton Applied
Research 273 potentiostat and associated computer software for corrosion measurements. A scan rate of $500 \mathrm{mV} / \mathrm{min}$ was used in the range of -800 to $+1600 \mathrm{mV}$ (SCE).

\section{Results and discussion}

\subsection{Microstructure characterization}

Fig. 2 shows a typical metallograph displaying the crosssection of laser-clad layers on a mild steel substrate, in which the overlapping of successive trucks is clearly identifiable. The clad layer is defect-free of approximately $0.4 \mathrm{~mm}$ thick and forms an excellent metallurgical bond with the substrate. During the coaxial laser cladding process, the power attenuation by Stellite 6 powder was about $56 \%$ as measured by a power meter under experimental conditions. The power attenuation could be obtained from the ratio of power reading with powder stream (which was blown away by compressed air at the same stand-off distance as in the laser cladding process) to that without powder stream. The effect of power attenuation would reduce the energy absorbed by the substrate and also minimize the dilution between the clad layer and the substrate.

It is known that surface welding generally results in residual tensile stresses due to the contraction during solidification and may form cracks in the surface layer [15]. Moreover, the difference in thermal expansion coefficients between the cladding material and the substrate
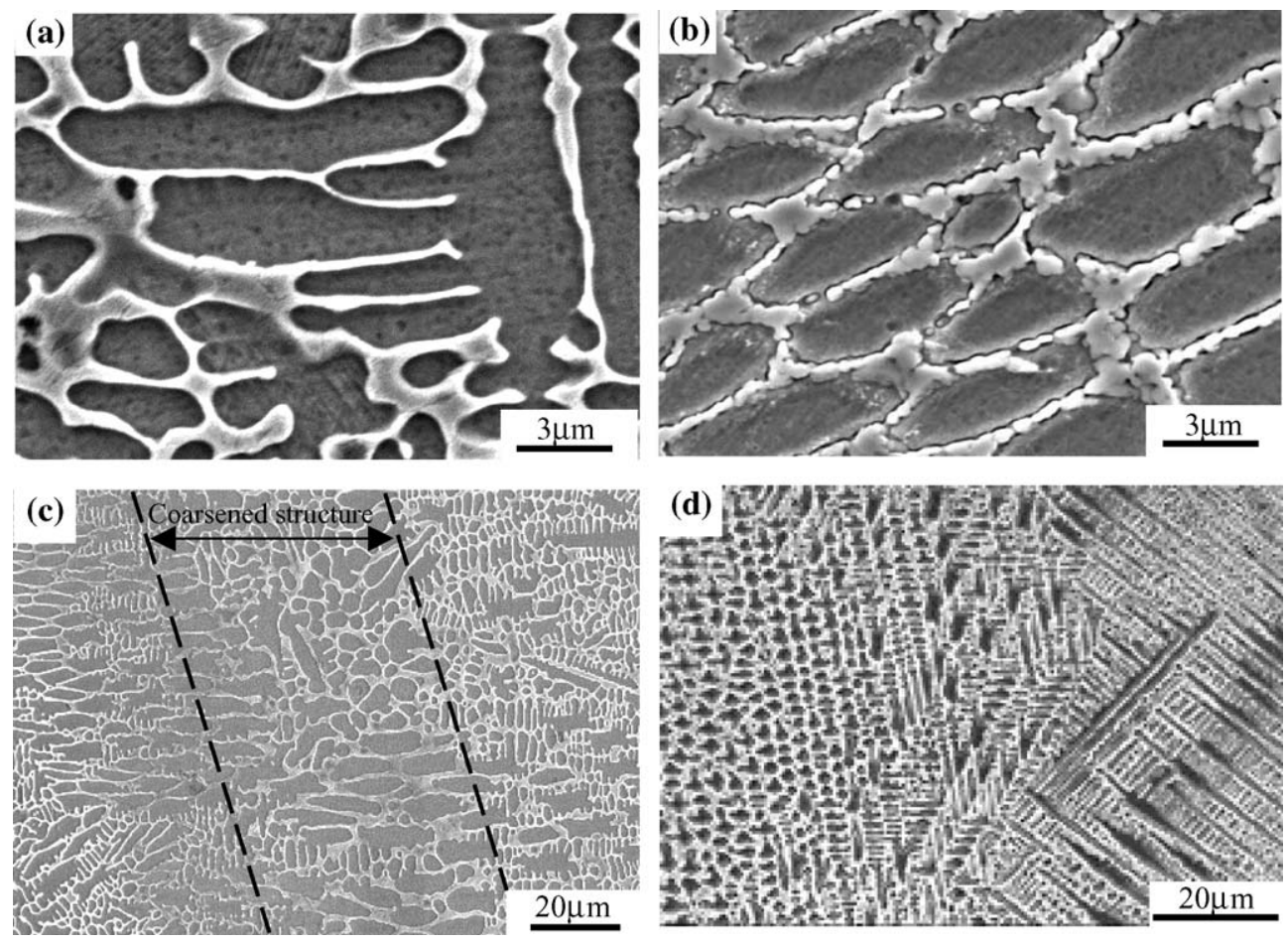

Fig. 3. SEM photographs showing the microstructure in laser-clad layers: (a) and (b) the central part of an individual laser truck of S-6 and T-900 specimens, respectively; (c) and (d) the overlapped area of successive laser tracks of S-6 and T-900 specimens, respectively. 
enhances the residual stress. As a result, it is often required to preheat the substrate in order to reduce residual stresses in the process. It was suggested that a preheat temperature of $250{ }^{\circ} \mathrm{C}$ should be employed during laser cladding of T-900 specimens to avoid cracking. In this investigation, S-6 and 410 SS specimens were processed at room temperature without forming cracks. However, preheat might be required as the cladding thickness increased so as to reduce the effect of welding residual stresses.

The as-deposited structures of laser-clad layers comprise of basically a hypoeutectic structure, containing primary dendrites and interdendritic eutectics. Fig. 3(a) and (b) show the microstructure in the central part of an individual laser track of S-6 and T-900 specimens, respectively. In overlapped area of successive laser tracks, a slightly coarsened structure is observed in the S-6 specimen as illustrated in Fig. 3(c). However, such a coarsening effect is less obvious in the T-900 specimen and the microstructure in overlapped area often reveals only a change in growth direction during solidification as shown in Fig. 3(d).

Owing to rapid cooling of the laser cladding process, the resulting microstructure of the clad layer is much finer than that of the conventional welding processes. Fig. 4 shows the microstructure of the Stellite 6 weld overlay deposited by a plasma-transferred arc (PTA) process. The parameters used to make such an overlay were as follows: a current of $140 \mathrm{~A}$, a voltage of $22.5 \mathrm{~V}$, a travel speed of $20 \mathrm{~cm} / \mathrm{min}$, and a powder feed rate of $11 \mathrm{~g} / \mathrm{min}$. The PTA process is also known to have higher deposition rate and lower energy input, which is widely used in the industry for various wear applications [16]. The energy input is computed as the total input power of the heat source to the process speed, ignoring the heat transfer efficiency for simplicity. The calculated energy input of PTA is about $950 \mathrm{~J} / \mathrm{mm}$, higher than $250 \mathrm{~J} /$ $\mathrm{mm}$ of laser processed specimens. Owing the high reflectivity of metal surfaces, the net energy input in laser cladding could be significantly lowered. The lower energy input of laser cladding causes the higher cooling rate of the clad layers. Consequently, the dendrites are much finer in the laser-clad specimen than those in the PTA processed specimen as shown in Fig. 4.

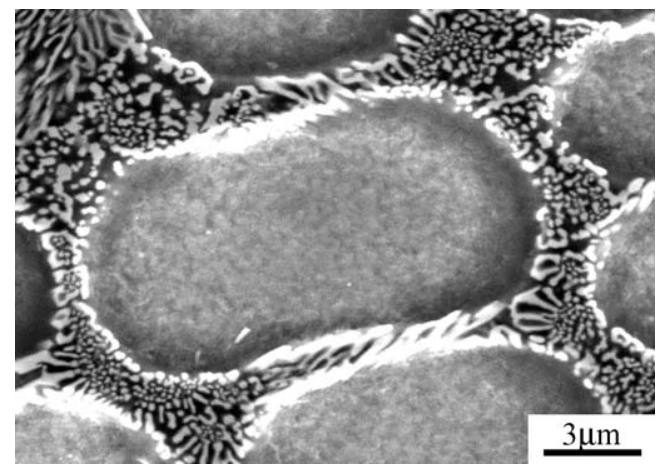

Fig. 4. Microstructure of the clad layer of Stellite 6 deposited by a plasmatransferred arc (PTA) process.
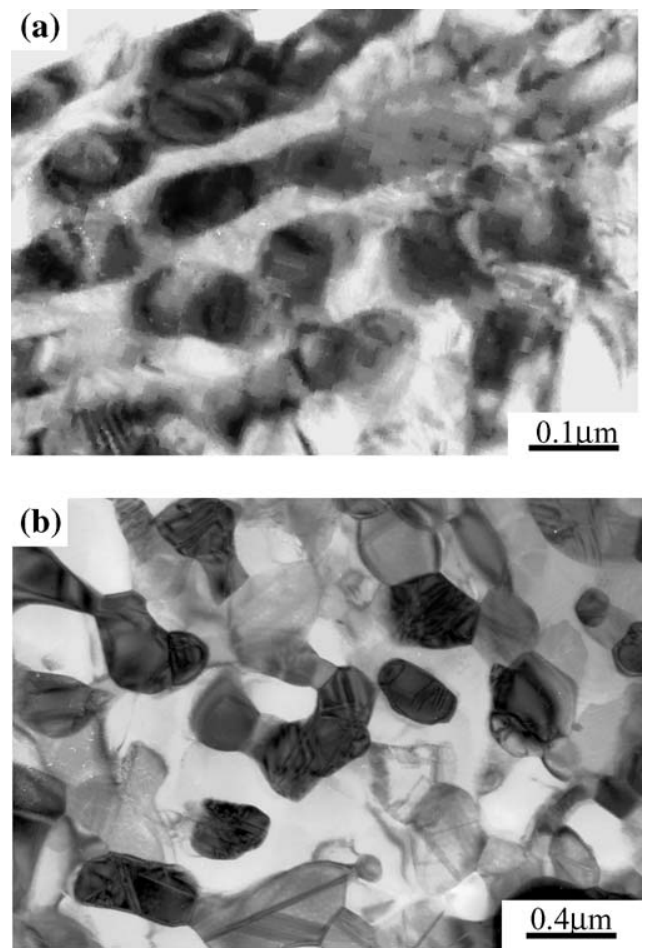

Fig. 5. TEM micrographs showing the interdendritic region of (a) S-6 and (b) T-900 specimens.

The eutectic structures in Fig. 3(a) and (b) are not apparent but can be observed clearly under high magnification. TEM analyses of the clad layers of S-6 and T-900 specimens reveal that the dendrites are, in fact, cobalt-based solid solution ( $\gamma$, face-centered-cubic). At interdendritic regions as shown in Fig. 5, the major constituent other than $\gamma$ in eutectics consists of $\mathrm{M}_{7} \mathrm{C}_{3}(\mathrm{M}=\mathrm{Cr}, \mathrm{Co}, \mathrm{W})$ [1] and Laves phase (CoMoSi) [17] for S-6 and T-900 specimens, respectively. The presence of $\mathrm{M}_{7} \mathrm{C}_{3}$ (orthorhombic, $\mathrm{a}=0.701$ $\mathrm{nm}, \mathrm{b}=1.215 \mathrm{~nm}$, and $\mathrm{c}=0.453 \mathrm{~nm}$, JCPDS file 36-1482) and CoMoSi Laves (hexagonal, $\mathrm{a}=0.4745 \mathrm{~nm}$ and $\mathrm{c}=0.757$ nm, JCPDS file 15-0419) has been confirmed by electron diffraction patterns. Note that these small carbides and intermetallic compounds are randomly distributed in a

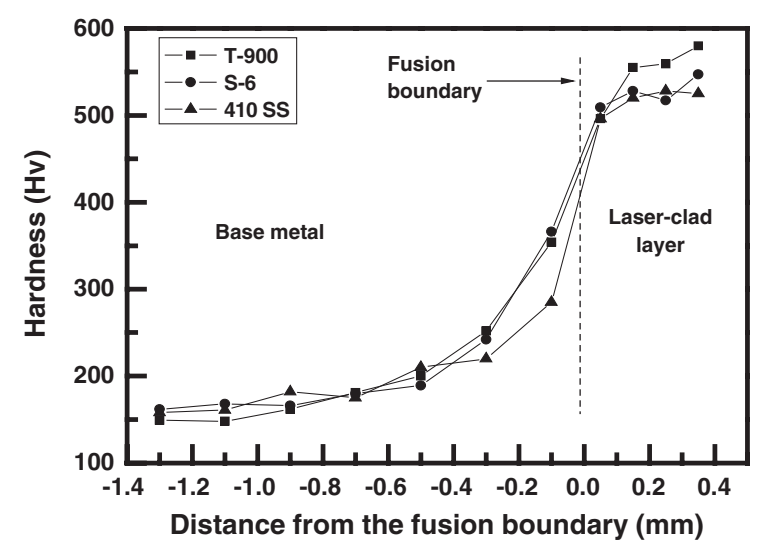

Fig. 6. Microhardness profiles for various laser-clad specimens. 
cobalt-rich solid solution, unlike the lamellar form as shown in Fig. 4.

\subsection{Hardness and wear resistance}

Fig. 6 gives the hardness profile of laser-clad specimens, in which the average hardness of T-900, S-6, and $410 \mathrm{SS}$ specimens within the top $0.25 \mathrm{~mm}$ coating layers is 564 , 530 , and $526 \mathrm{Hv}$, respectively. Clearly, the T-900 specimen has the highest hardness among various specimens being tested, while the hardness of the S-6 specimen is about the same as that of the 410 SS specimen. Fig. 6 also shows that the hardness of clad layers is much higher than the substrate and the hardness decreases slightly near the fusion boundary, indicating the existence of a narrow region of dilution in specimens. EDS analyses indicated the lack of iron on the top $0.25 \mathrm{~mm}$ of the clad layers and then a gradual increase in iron concentration towards the fusion boundary.

The wear loss of various laser-clad specimens against sliding distance in wear tests is shown in Fig. 7. The wear loss increases in the order through the T-900, S-6, and 410 SS specimens. For instance, the wear loss of the T-900 specimen after sliding distance of 1000 meters is $11 \mathrm{mg}$, which is noticeably less than $17 \mathrm{mg}$ and $61 \mathrm{mg}$ of S-6 and 410 SS specimens, respectively. Apparently, Laves intermetallics in the T-900 specimen contribute appreciably to the wear resistance. The superior wear resistance of cobaltbased alloys over an iron-based alloy at the similar hardness level is evident. It is noted that the wear rate, slope of the wear curves in Fig. 7, is nearly constant for S-6 and T-900 specimens. However, the wear rate of the 410 SS specimen is considerably higher in the initial $300 \mathrm{~m}$ than the last 700 $\mathrm{m}$ of sliding distance, i.e. an obvious change in slope of the wear curve occurs at approximately $300 \mathrm{~m}$. This could be attributed to the greater extent of (1) reduction in the cutting efficiency of the abrasive particles through capping and clogging $[18,19]$ and (2) to working hardening in the subsurface region [20].

Fig. 8 shows the worn surfaces of laser-clad specimens after wear tests. The worn surfaces of S-6 and T-900

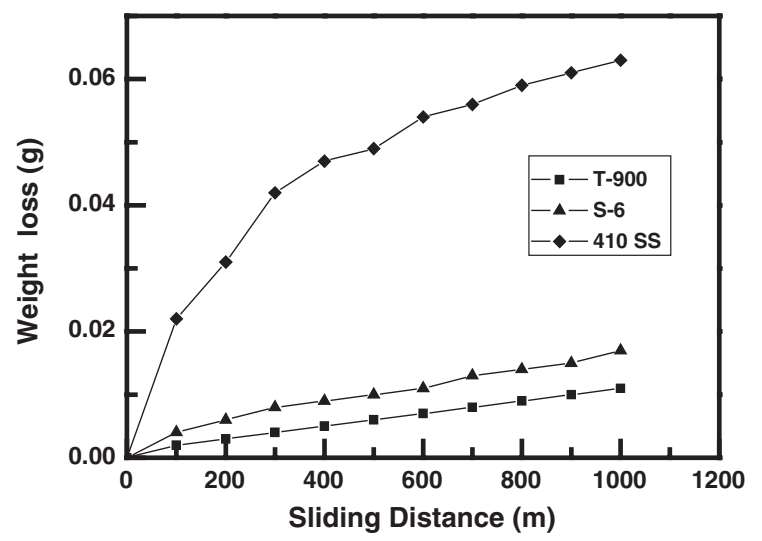

Fig. 7. Wear loss as a function of sliding distance for laser-clad specimens.
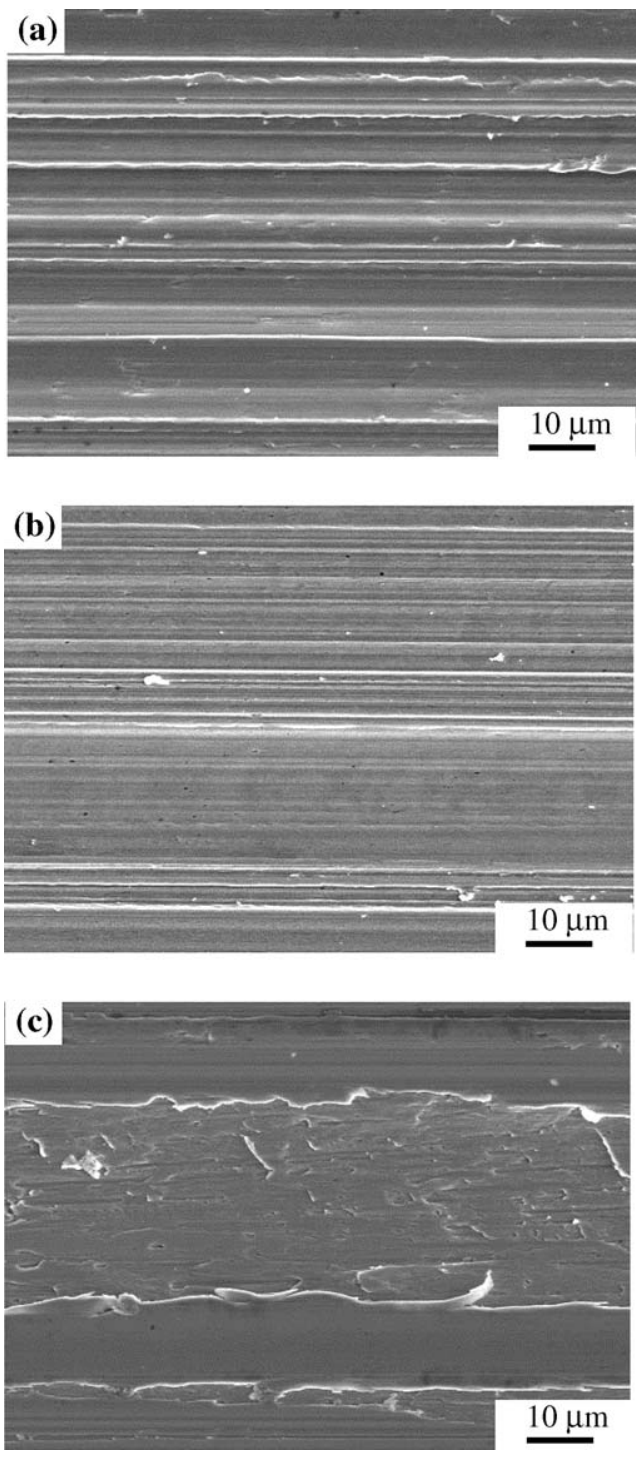

Fig. 8. SEM photographs showing the worn surfaces of (a) S-6, (b) T-900, and (c) 410 SS specimens after wear tests.

specimens (Fig. 8(a) and (b)) appear to be similar, showing the effect of microploughing and grooving on specimens by hard $\mathrm{SiC}$ particles during abrasive wear. However, the shallower grooves are observed on the worn surface of the T-900 specimen. In contrast, the 410 SS specimen (Fig. 8(c)) reveals extensive ploughing together with oxidational wear on the worn surface. In addition, fins are also observed at edges of the groove and they are eventually to break off, resulting in a higher wear loss of the 410 SS specimen.

It should be mentioned that the wear resistance is not only dependent on the cladding hardness and the hardness of Stellite 6 coatings is strongly dependent on solidification microstructures [21]. The wear resistance is also a function of some other factors such as the modulus of elasticity, microstructure including the size and distribution of hard particles in the alloy, size and hardness of abrasive particles, sliding distance, and applied load [3]. For example, the hardness of Stellite 6 overlays deposited by PTA process is 

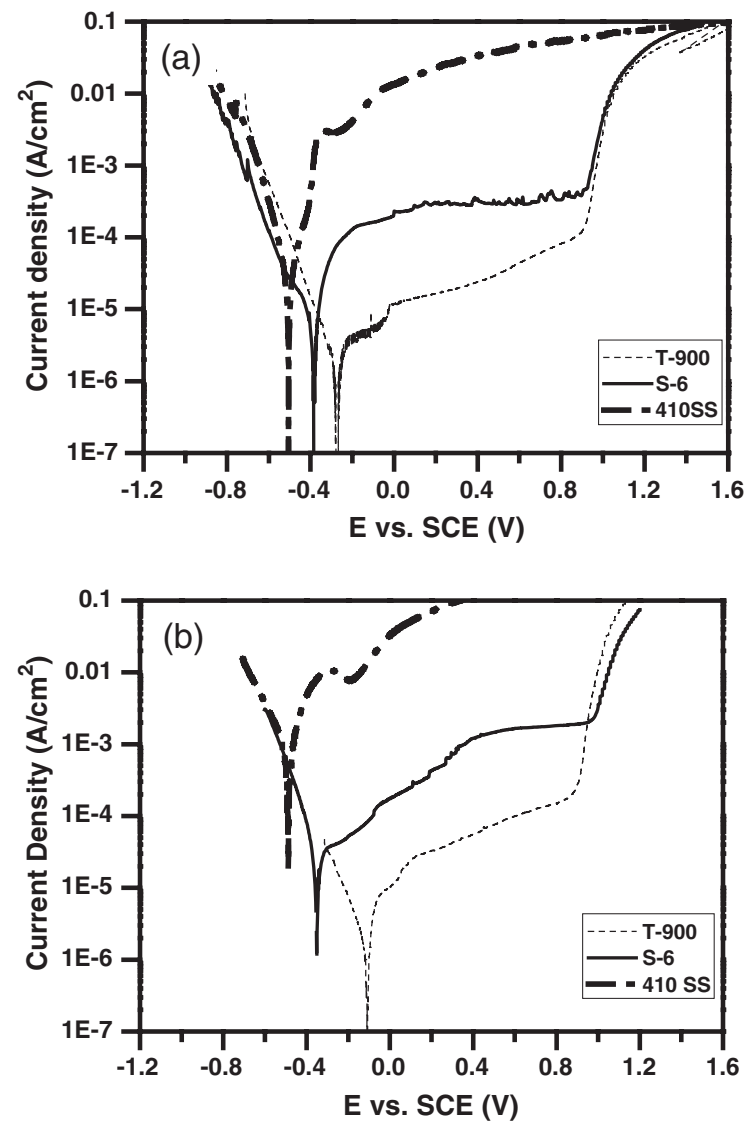

Fig. 9. Potentiodynamic curves of three laser-clad specimens in (a) $0.1 \mathrm{M}$ and (b) $0.5 \mathrm{M} \mathrm{HCl}$ solutions of at room temperature.

$450 \mathrm{Hv}$, which is considerably less than $530 \mathrm{Hv}$ of laser-clad S-6 specimens. The same trend has been observed for the T900 PTA weld deposit [9]. The low hardness of PTA overlays is attributed to the presence of coarse solidification structures as discussed previously. However, the wear loss of the PTA overlay after $1000 \mathrm{~m}$ sliding distance is $10 \mathrm{mg}$, which is similar to that of T-900 but less than $17 \mathrm{mg}$ of the S-6 specimen. Apparently, the fine carbides associated with S-6 specimens are readily pulled out rather than worn down in the abrasive wear tests. This is consistent with the report that the abrasive resistance of Stellite alloys is improved as the carbide size increases [1].

On the other hand, alloys used for abrasive protection may not suitable for erosion resistant applications because different wear mechanisms are involved. It has been reported that the weld overlay coatings of Stellite 6 $(\sim 445 \mathrm{Hv})$ exhibit relatively poor erosion resistance compared to the erosion resistance of Inconel $625(\sim 235$ $\mathrm{Hv})$ and $316 \mathrm{~L}$ stainless steel $(\sim 185 \mathrm{Hv})$ [22]. It can be concluded that a higher hardness of the clad layer does not necessarily guarantee to have better wear performance, since wear resistance, as pointed out by Antony [1], is a system parameter rather a material property. Consequently, most of the successful applications of cladding materials were gained by experiments under specific conditions.

\subsection{Potentiodynamic behavior}

Potentiodynamic curves of three laser-clad specimens exposed to $0.1 \mathrm{M}$ and $0.5 \mathrm{M} \mathrm{HCl}$ solutions at room temperature are displayed in Fig. 9(a) and (b), respectively. It can be seen that no active-to-passive transition peaks for S-6 and T-900 specimens, indicating that the clad layers of these specimens were passivated spontaneously in these solutions. The corrosion potential of T-900 specimens is $-274 \mathrm{mV}$ and $-110 \mathrm{mV}$ in $0.1 \mathrm{M}$ and $0.5 \mathrm{M} \mathrm{HCl}$ solutions, respectively. These values are more noble than the corrosion potential of S-6 specimens in the solution of concern, i.e. $-384 \mathrm{mV}$ in $0.1 \mathrm{M} \mathrm{HCl}$ and $-351 \mathrm{mV}$ in $0.5 \mathrm{M} \mathrm{HCl}$ solutions. It is noted that the $410 \mathrm{SS}$ specimen does not reveal an active-to-passive transition but exhibits a rapid increase in current density with increasing potential in both $0.1 \mathrm{M}$ and $0.5 \mathrm{M} \mathrm{HCl}$ solutions. The corrosion potential of the $410 \mathrm{SS}$ specimen in these solutions is more active than that of cobalt-based alloy specimens.

The corrosion current density $\left(I_{\text {corr }}\right)$ is determined by the Tafel extrapolation method [23] from potentiodynamic curves in Fig. 9. The linear portion of the anodic or cathodic polarization potential vs. log (current) plot is extrapolated to intersect the potential line. The value of either the anodic or the cathodic current at the intersection is $I_{\text {corr }}$ in the Tafel plot. Although a fully linear portion of the curve is not necessary to calculate $I_{\text {corr }}$ by the associated software of the potentiostat, the better accuracy of $I_{\text {corr }}$ requires the longer linear region in the Tafel plot. The corrosion rate ( $\mu \mathrm{m} /$ year) is related to $I_{\text {corr }}$ by the equation (Faraday's law) with the assumption of $n$ (number of electrons taking part in the reaction) equals to 2 .

Corrosion rate $(\mu \mathrm{m} /$ year $)$

$$
=\frac{3.27\left(I_{\text {corr }}, \mu \mathrm{A} / \mathrm{cm}^{2}\right)(\text { Equivalent weight, } \mathrm{g})}{\left(\text { Density }, \mathrm{g} / \mathrm{cm}^{3}\right)}
$$

It is worthwhile to mention that the above equation is only valid in cases of uniform corrosion and can be used to index the relative corrosion resistance of metals in a specific environment.

Table 3 lists the corrosion current density $\left(I_{\text {corr }}\right)$ and the corrosion rate $(\mu \mathrm{m} /$ year) of laser-clad specimens in $\mathrm{HCl}$ solutions. The calculated equivalent weight and the associ-

Table 3

Corrosion rate of various laser-clad specimens exposed in $\mathrm{HCl}$ solutions

\begin{tabular}{llcc}
\hline Solution & Specimen & $I_{\text {corr }}\left(\mu \mathrm{A} / \mathrm{cm}^{2}\right)$ & Corrosion rate $(\mu \mathrm{m} / \mathrm{y})^{\mathrm{a}}$ \\
\hline $0.1 \mathrm{M} \mathrm{HCl}$ at & S-6 & 4.153 & 45 \\
$25{ }^{\circ} \mathrm{C}$ & $\mathrm{T}-900$ & 1.327 & 15 \\
& $410 \mathrm{SS}$ & 44.91 & 519 \\
$0.5 \mathrm{M} \mathrm{HCl}$ at & $\mathrm{S}-6$ & 48.01 & 516 \\
$25{ }^{\circ} \mathrm{C}$ & $\mathrm{T}-900$ & 2.049 & 23 \\
& $410 \mathrm{SS}$ & 915.5 & 10580 \\
\hline
\end{tabular}

a $1 \mu \mathrm{m} /$ year $\cong 0.04 \mathrm{mpy}$ (milli-inches per year). 
ated density of S-6, T-900, and 410 SS specimens are 27.75 $\mathrm{g} / 8.44 \mathrm{~g} / \mathrm{cm}^{3}, 30.42 \mathrm{~g} / 8.85 \mathrm{~g} / \mathrm{cm}^{3}$, and $27.39 \mathrm{~g} / 7.75 \mathrm{~g} / \mathrm{cm}^{3}$, respectively. As can be seen in Table 3, the corrosion rate of $\mathrm{T}-900$ specimens in either $0.1 \mathrm{M} \mathrm{HCl}(15 \mu \mathrm{m} /$ year $)$ or $0.5 \mathrm{M}$ $\mathrm{HCl}(23 \mu \mathrm{m} /$ year $)$ is the lowest among specimens being tested. The T-900 specimen has a corrosion rate about 33\% of the S-6 specimen in $0.1 \mathrm{M} \mathrm{HCl}$, but it becomes less than $5 \%$ of the S- 6 specimen in $0.5 \mathrm{M} \mathrm{HCl}$ solution. The $I_{\text {corr }}$ of the $410 \mathrm{SS}$ specimen is approximately $45 \mu \mathrm{A} / \mathrm{cm}^{2}$ in $0.1 \mathrm{M}$ $\mathrm{HCl}$ and raises to $916 \mu \mathrm{A} / \mathrm{cm}^{2}$ in $0.5 \mathrm{M} \mathrm{HCl}$ solutions. These values are much higher than the $I_{\text {corr }}$ values of cobaltbased alloy specimens in respective solutions. The corrosion rate of the $410 \mathrm{SS}$ specimen is about $519 \mu \mathrm{m} /$ year in $0.1 \mathrm{M}$ $\mathrm{HCl}$ and reaches an extremely high level of $10,580 \mu \mathrm{m} /$ year in $0.5 \mathrm{M} \mathrm{HCl}$ solution.

The superior corrosion resistance of cobalt-based alloy specimens, particularly Tribaloy T-900, when compared to the corrosion resistance of the 410 SS specimen in hydrochloric acid solution has been demonstrated. It has been reported that the corrosion resistance of Stellite alloys is generally good in many acids but poor in hydrochloric acid [1]. The potentiodynamic behavior of various laser-clad specimens in hydrochloric acid solution could be used to index their relative corrosion resistance in a hostile environment. From the results discussed above, the advantages of laser coating cobalt-based alloys on metal components are evident, not only to improve the wear resistance but also to enhance corrosion protection. However, the selection of cladding materials for corrosion protection is also dependent on the environment in a particular application.

\section{Conclusions}

(1) Surface modification of metal components can be achieved by coaxial laser cladding alloy powders onto the area of interest. This process could produce thin surface layers of less than $0.5 \mathrm{~mm}$ with low energy input. It is well suitable for anti-wear/corrosion applications where a thin clad layer and a strong bond to the substrate are required.

(2) S-6 and T-900 laser-clad layers exhibited refined dendrites with eutectics at the interdendritic regions. These regions consisted of small carbides or Laves particles randomly distributed in cobalt-rich solid solution, not necessarily in lamellar form. Laser-clad Stellite 6 layers had the average hardness higher than PTA weld overlays, but did not have better wear performance.

(3) The wear resistance of laser-clad layers decreased in order through the T-900, S-6, and 410 SS specimens under experimental conditions. The T-900 specimen had the highest hardness and the lowest wear loss among the tested specimens. In contrast, S-6 and 410 SS specimens had similar hardness but the latter exhibited a significantly higher wear loss in the abrasive wear test.

(4) The corrosion resistance of cobalt-based alloy specimens was better than that of the $410 \mathrm{SS}$ specimen in $0.1 \mathrm{M}$ and $0.5 \mathrm{M} \mathrm{HCl}$ solutions. The T-900 specimen also had substantially lower corrosion rates than the S6 specimen in such solutions. The excellent wear and corrosion characteristics of the former were obvious, however, preheating was required to avoid cracking during the laser cladding process.

\section{Acknowledgement}

The authors gratefully acknowledge the support the Republic of China National Science Council (Contact No. NSC91-2216-E-002-032).

\section{References}

[1] K.C. Antony, JOM 35 (2) (1983) 52.

[2] W.L. Silence, J. Lub. Technol., Trans. ASME 100 (1978) 428.

[3] K.J. Bhansali, W.L. Silence, Met. Prog. 112 (6) (1977) 39.

[4] A.J. Hickl, JOM 32 (3) (1980) 6.

[5] Cobalt-Base Rods, Electrodes and Wires (W-207), 1982, Stellite Wear Technology, Cabot Corporation, Kokomo, Ind.

[6] J.L. De Mol Van Otterloo, J.Th.M. de Hosson, Acta Mater. 45 (1997) 1225 .

[7] Tribaloy Wear Resistance Intermetallic Materials (W-152), 1980, Wear Technology Division, Cabot Corporation, Kokomo, Ind.

[8] A. Halstead, R.D. Rawlings, J. Mater. Sci. 20 (1985) 1693.

[9] Tribaloy T-900 Technical Data, Stellite Coating Division, Deloro Stellite Company, Inc., Goshen, Ind., 2002.

[10] W.M. Steen, in: D. Belforte, M. Levitt (Eds.), The Industrial Laser Annual Handbook, SPIE, vol. 629, PennWell, Tulsa, OK, 1986, pp. $158-174$.

[11] G.J. Bruck, JOM 39 (2) (1987) 10.

[12] P.J.E. Monson, W.M. Steen, Surf. Eng. 6 (3) (1990) 185.

[13] A. Hirose, K.F. Kobayashi, ISIJ Int. 35 (6) (1995) 757.

[14] H.C. Wu, L.W. Tsay, C. Chen, ISIJ Int. 44 (10) (2004) 1720.

[15] A. Sofia, C.M. D’Oliveria, P. Sergio, C.P. da Silva, R.M.C. Vilar, Surf. Coat. Technol. 153 (2002) 203.

[16] K.G. Budinski, Surface Engineering for Wear Resistance, PrenticeHall, Englewood Cliffs, NJ, 1988, pp. 218-241.

[17] J. Przybylowicz, J. Kusinski, Surf. Coat. Technol. 125 (2000) 13.

[18] A.P. Mercer, I.M. Hutching, Wear 132 (1989) 77.

[19] A. Mishra, I. Finnie, Wear 68 (1981) 41.

[20] O.P. Modi, B.K. Prasad, S. Das, A.K. Jha, A.H. Yegneswaran, Mater. Trans., JIM 35 (1994) 67.

[21] A. Frenk, W. Kurz, Wear 174 (1994) 81.

[22] B.F. Levin, J.N. Dupont, A.R. Marder, Wear 181-183 (1995) 810.

[23] M.G. Fontana, Corrosion Engineering, 3rd ed., McGraw-Hill, New York, 1986, pp. 482-504. 